\title{
THE STUDY OF LAW IN ROMAN LAW SCHOOLS
}

Roman law, which furnished to the world the priceless gift of a completed system of private law actually answering "to the true nature of private law" 1 is still "of great practical importance to the American lawyer of the future," 2

"The civil law, for purposes of comparative jurisprudence and because of its more orderly and scientific arrangements, should in its great outlines and essential character be made an element of instruction to a greater extent than it is in our American law schools;"3 and these remarks of Judge Dillon, sixteen years ago, now re-echo with increasing force, if for no other reason than the addition to our country, as a result of the Spanish war, of insular dependencies wherein the common law is directly based upon the Roman law. The civil law has directly or indirectly passed into the jurisprudence of every civilized country of the world, and is still potent to help us form rules for the business of life. The fact of the resurrection of Roman law in modern English law is strongly attested by Sir Frederick Harrison: "The present generation has witnessed a really striking phenomenon. This is no less than the re-annexation of the English law on to the great body of principle of which the Roman law is the basis and framework. Henceforward the insularity of English law is a thing of the past."

The civil law, as the jurisprudence of the Roman state, had a continuous existence and development for nearly thirteen centuries, or over 2,200 years, if we but pause at the reign of Justinian and then pass on to that fateful day in the year 1453 when the Roman eagles fell, never to rise again, at the capture of Constantinople by the Turks. What light, if any, can the law of Rome throw upon the problem of how to give the best legal training and equipment to persons engaged in the study of law? Our investigation will afford an opportunity to notice how our system of legal education compares in quality with Roman legal

I. A. H. F. Lefroy, "Rome and To-day," 20 Harvard Law Review, p. 606, (1907).

2. Prof. W. F. Foster, Yale Law School, "The Study of Roman Law," 3 Yale Law Journal, p. 215, (1898).

3. Dillon, Lectures on Law and Jurisprudence, p. 86.

4. 3I Fortnightly Review, p. 129. 
education. We in America are passing through a period of advancement and progress in legal education; the standards of work required of our law students are being pushed higher and higher; the course of study is being lengthened,-three years of study are now required by our most progressive law schools; and all our methods of law teaching are "under fire,"-although the champions of the case system of instruction claim that their method of "teaching law from start to finish by means of cases as a basis" 5 is superior to all other pedagogic methods hitherto employed.

Roman jurisprudence may be said to date from the college of priests $^{6}$ who acted as skilled legal advisers in the royal and early republican courts of Rome. This pontifical jurisprudence, so long a secret science, was published to the world about the year 254 B. C. by Tiberius Coruncanius, the earliest plebeian pontiff, who first avowed himself a public jurisconsult ${ }^{7}$-announcing that he was prepared to answer questions put to him by persons desiring to know the law. Thereafter legal knowledge was open to all, the beginning of a system of public legal instruction commenced, and presently there followed the development of a legal literature, the "cradle" of which was a commentary on the Twelve Tables and the pontifical proceedings for actions and juristic acts. ${ }^{8}$ Soon the influence of Greek literature and particularly, the scientific methods of Stoic philosophy, suggested the idea of shaping law into a rational artistic form. Cato the younger ${ }^{9}$ first made this attempt to set forth law in a systematic order, but the undertaking was fully accomplished in the year roo B. C. by Scaevola the younger, whose system of arrangement and classification of positive law according to the nature of the subject-matter treated became the foundation upon which the successive jurists builded. Law now first appears in scientific dress,-Scaevola laid down general legal conceptions and outlined legal institutions (wills, legacies, guardianship, contracts such as sale, etc.). The chief business of Roman legal practitioners now became more easy. Their functions were to answer legal

5. See Prof. John Wurts, "Systems in Legal Education," I7 Yale Law Journal, 86, (1907).

6. Pontifices.

7. Primus profiteri coepit (Cicero, Planc. 8); publico professum (Digest I, 2, 2 Pomponius, 35).

8. The "Tripertita" (Digest 1, 2, 2 Pomponius, 38) of Sextus Aelius Catus, consul rg8 B. C.

9. Died 152 B. C. 
questions, ${ }^{10}$ act in court for clients, ${ }^{11}$ and draw up the proceedings for juristic transactions. ${ }^{12}$ With these duties, the Roman jurisconsult would combine writing on legal subjects and teaching law.

The era of private law schools now begins: any jurisconsult who could collect a following of students was not hindered by law from giving legal instruction to them. His freedom to teach law was unrestricted, and this condition of things lasted for at least 300 years-marking the golden era of classical jurisprudence under the early empire-down to the last of the jurists properly so-called, or to the era of state law schools which was ushered in at about the time of Diocletian (284-305 A. D.).

At the very outset, in the time of Augustus, two rival schools sprang up whose rivalry lasted as late as the reign of Marcus Aurelius. ${ }^{18}$ Perhaps their origin was due to that privilege ${ }^{14}$ bestowed by Augustus and his successors upon certain jurists, whereby their legal opinions, once delivered, bound the magistrates and appointed referees ${ }^{15}$ and became a source of law. These two schools bore the name of Sabinians and Proculians, each of which was so named from a disciple of its founder. ${ }^{16}$ The essential difference between these two schools cannot now be determined. Some of this divergence was due to the personnel of the teachers. In a general way, the Proculians were inclined to abide by traditional rules, while the Sabinians preached progress for Roman law by getting rid of its old-fashioned formalism. Both Capito and Labeo, their founders, ${ }^{17}$ gave legal instruction after the traditional fashion prevalent under the republic, which was to allow young men to be present as listeners ${ }^{18}$ while the jurisconsults gave opinions and to permit them to see how they conducted their law business, ${ }^{19}$ occasionally arguing with their pupils but rarely giving private instruction by means of connected lectures. This practical instruction was, under the empire, supplemented by teaching the students the elements of

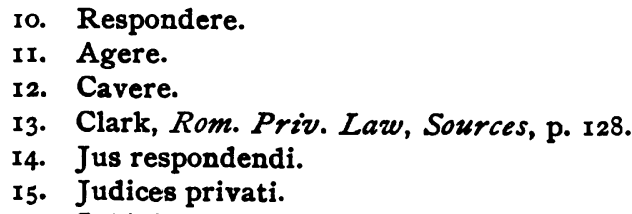

Io. Respondere.

II. Agere.

12. Cavere.

13. Clark, Rom. Priv. Law, Sources, p. 128.

14. Jus respondendi.

15. Judices privati.

16. Sabinians, from Sabinus, follower of Capito; Proculians, from Proculus, follower of Labeo.

17. Capito, of the Sabinians; Labeo, of the Proculians.

18. Auditores.

19. Cicero, Brut. 89, Laelius, 1. 
law, as expressed by the term "Institutes." 20 Sabinus, who, according to Pomponius, supported himself by giving legal instruction ${ }^{21}$ was very likely the first to originate a real school of law; and he doubtless adopted the mode of giving instruction through a corporate organization, which had been prevalent among Greek schools of philosophy. These were societies of which the students were the members and the "professor," 22 the society's head or president, to whom the students upon entering paid fees for tuition. One "professor" used to succeed another as "president" by legal succession. Certainly Sabinus was in the habit of taking fees from his pupils, according to Pomponius, ${ }^{23}$ who moreover, always used the term "succedit" 24 in enumerating the heads of the Sabinian and Proculian schools,- - a term avoided in enumerating the republican jurists. Ulpian also speaks of the fee payable to the "professor."25 The other school-the Proculians-organized in the same way. Their founder, Labeo, was a man of extraordinary ability, who, possessed of great power of definition, gave terse and vigorous utterance to many legal principles already recognized as "in the air."

The organized opposition of the two schools or societies lasted down into the reign of $\mathrm{Hadrian}^{26}$ ( I $\left._{7} \mathrm{I}^{-1} 3^{8}\right)$, when owing to the reputation and influence of the then head of the Sabinians, the illustrious Julian, "all became Sabinian and the Proculians died out."27 The jurists Gaius and Cervidius Scaevola were

20. "Institutiones." Distinguished jurists, especially from the time of Hadrian to Alexander Severus (II 7-235 A. D.) were in the habit of writing elementary treatises for the use of students. Papirius Justus, Callistratus, Paulus, Marcian, Florentinus, and Gaius all published "Institutiones." Paulus also published his "Sententiae," and Ulpian his "Regulae."

21. Dig. 1, 2, 2, 50 .

22. "Magister," or " antecessor," or " professor."

23. Dig., 1, 2, 2, 50.

24. Dig., 1, 2, 2, 5 I.

25. Dig., 50, 13, I, 5 .

26. See Clark, op. cit., page II9, 128 .

27. Karlowa, Röm. Rechtsgeschichte, I, 709. Gaius, who died I80 A.D., mentions contemporary teachers of the Proculians, but their names have not come down to us. From Augustus to Hadrian (died 138 A.D.) the heads of these two schools were:-Of the Proculians,-Labeo, Proculus, Pegasus (whose pupil may have been the celebrated Pomponius, Dig. 34, 43, 2), Celsus (Juventius), and Neratius (Priscus); Of the Sabinians,-Capito, Sabinus (Massurius), Cassius (Longinus), Sabinus (Caelius), Javolenus, and Julian (whose most famous pupils were the celebrated jurists, Paulus and Africanus, while Papinian "the prince of jurisconsults," was an instructor under Julian.)

See Clark, op. cit., page 107-129; Digest, 1, 2, 2. 
largely Sabinian, while Ulpian, whose writings form the groundwork of the Digest of Justinian, and who died nearly one hundred years after Hadrian, ${ }^{28}$ wrote a commentary in fifty-one books on Sabinus.

Toward the end of the second century of the Christian era there were many fixed places at Rome-probably near the law courts-where law was studied. ${ }^{2}$ Schools of law soon spread over the empire: in the beginning of the third century a school of law was established at Berytus ${ }^{30}$-modern Beirut-Syria (of which Ulpian was probably a professor $)^{31}$, rivalling the earlier school of Rome and the school at Constantinople founded in the fifth century.

In the early empire down nearly to the fourth century the teaching of the law was without state support; but in the time of Diocletian (284-305) the advent of the "state law school" is at hand,-state recognition seems to have been extended to the law schools of Rome and Berytus, and considerably later to those of Constantinople, Alexandria, and Cæsarea. ${ }^{32}$ In the year 425 A.D. the emperor Theodosius the younger established a university at Constantinople apparently in imitation of that already existing at Rome. ${ }^{33}$ This enactment instituted two professorships in law, as well as professorships in the arts, required the professors to give public lectures, and forbade all other persons in these cities to exercise this privilege. It is as follows: "Concerning the study of the liberal arts in the cities of Rome and Constantinople. The emperors Theodosius and Valentinian to the city prefect. We decree that all persons, who, usurping the title of professor, have been accustomed to assemble in public schools or rooms pupils collected from everywhere, cease to do so; and if anyone, after the publication of this law, shall again attempt what we forbid and condemn, not only shall he be marked with infamy, which he deserves, but he shall be driven ont of the city wherein he is acting unlawfully. But we do not prohibit by any threat of such punishment those persons, who have been accus. tomed to impart instruction privately in the homes of most of

28. 228 A.D.

29. Aulus Gellius, XIII, 10, 13, who wrote 169-175 A.D.

30. Mackenzie, Rom. Law, page 16.

31. Roby, Introduction to the Digest, page CXCVII: Ulpian's pupil was Modestinus, the last jurist of note, (Id. page CXCIX).

32. See Muirhead, Law of Rome, $2 d$ ed. page 400 ; Karlowa, op. cit., I, page roon, et seq.; Heimbach, Prolegomena Basilicorum, I, ch. I, I-6, and II, $\mathrm{I}-2$.

33. Cod. Theodos., 14, 9; Cod. Justinian, I1, 8. 
their pupils, provided they abstain from teaching pupils except at their homes. But let those persons, who are appointed to teach in the auditorium of the Capitol, know that they are forbidden to give private instruction: if they are caught teaching contrary to this imperial statute, they shall be deprived of the privileges granted to them by reason of their appointment as professors at the Capitol. To our auditorium shall be attached, of the Latin language and literature three teachers of oratory and ten grammarians, and of the Greek language and literature five sophists and ten grammarians. And since we do not wish that ambitious young men be instructed merely in these arts, we will to the aforesaid professors join teachers of more profound sciences and learning. We wish to add to the rest, one to search the arcana of philosophy, and two others to disclose the processes of law and justice. Your excellency will take care that to each professor be assigned a special room, in order that the voices neither of pupils nor of professors resound against each other, and that no mingled confusion of languages or voices distract the ears of any persons from their studies and lectures. Given at Constantinople, February 26, in the eleventh consulship of Theodosius and that of the first of Valentinian (425)."

In the sixth century the law schools at Cæsarea (Syria) and Alexandria (Egypt) were suppressed in the year 533 A.D. by Justinian himself. ${ }^{34}$ The schools of law at the Roman university together with the university survived the occupation of Italy by the Ostrogoths, - a royal ordinance of Alaric, successor of Theodoric, relative to the University, makes mention of the professor of law, among other professors. ${ }^{35}$ When Justinian reconquered Italy in 554 , he specially provided for the maintenance of the Roman university professors fully as bountifully as did the Ostrogothic kings, ${ }^{36}$ and the course of study and meth. ods of teaching prescribed twenty years earlier for law schools of the East were applied to the law school at Rome. The later law schools at Ravenna in the eleventh century also helped to preserve the tradition of the legal teaching of the Roman empire as well as the Roman jurisprudence itself until the rise in the twelfth century of: the law school of Bologna, the mother of modern universities. In the ninth century the law schools at

34. Const. omnem.

35. Nec non et juris expositor,-Cassidorus, Var. IX, 21, and Amos, Civil Law of Rome, page ro3.

36. Quam et Theordoricus dare solitus est, -Epit. Julian, Nov. Tib. ch. XVII, and Ortolan 574 . 
Berytus and Alexandria-the latter seems to have somehow survived Justinian's suppression-still taught Roman law, being undisturbed for over a hundred years after the Mohammedan conquest. ${ }^{3} 7$

Under the later empire, systematic legal education was established in the course of time, and law students were obliged to study prescribed books in a certain order. No longer does legal training follow the whim of the particular law teacher. Furthermore, candidates for admission to the bar were required to pass a public examination before gaining the privilege to practice law. ${ }^{38}$

The required course of law study consisted of three years of study spent under professional instruction and two additional years of private study, thus altogether amounting to a five years' course. ${ }^{39}$ Justinian's reforms consisted largely in prescribing that thereafter-533 A.D.- students should be taught exclusively from the Justinian law books: for the books hitherto used by students did not suffice to give as sufficient and satisfactory a legal equipment in the sixth century, owing to the condition of the Roman law prior to its complete codification under Justinian.

Before discussing the scope and details of the programs of study before and after Justinian, it is interesting to note in passing that the students bore academic appellations or nick-names ${ }^{40}$ appropriate to the various years of their course; and that the faculties must have been bothered with questions of discipline and school government, just as now. The student names for their classes were very suggestive in the Latin and Greek tongues: the first-year students-the freshmen-were called, prior to Gustinian, "Two-pennies," 41 which Justinian changed to "Justinian's freshmen;" 42 the second-year men were called "Edictals," 43

37. T. P. Ion, "Roman law and Mohammedan law," 6 Michigan Law Review, pages 48-49, (1907), citing Kremer, Culturgeschichte des orients unter den Kalifen, I, 533. The Roman law survived the capture of Constantinople by the Turks and is still applied in the Greek church ecclesiastical courts between members of that faith in wills, marriage and divorce.

38. Mackenzie, Roman Law, page 387.

39. Const. omnem, I; Praefatio Institutionum, 2; Roby, op. cit., page XXVI, XXVII; Muirhead, op. cit., pages 400, 401 .

40. Const. omnem.

4r. Dupondii, "two-pounders," literally, Roby. op. cit., page XXVII.

42. Justiniani novi, "new Justinians," literally, Muirhead, op. cit., page 401 .

43. Edictales, because the Praetor's Edict was studied by them. 
while the third-year class bore the name of "Papinianists," 44 derived from that "prince of Roman jurisconsults;" but the Greek names for the next two years-the fourth and fifth-were indicative of and attested the progress of their holders: fourth-year men were called "Lytae," or "freed from lectures," 46 and fifth-year men, "Prolytae," or "advanced Lytae."45 Justinian himself legislated upon the government and discipline of the student body, in the very statute wherein he prescribed his new course of study, ${ }^{46}$ section nine reading: "We moreover forbid, under very severe penalties, those who study in our renowned city ${ }^{4}$ or in the fair town of Berytus, both to engage in those low and unworthy sports which suit only slaves, and which always end by injuring somebody, and to commit any offense ${ }^{48}$ either against their professors or against their fellow students, especially against those who are still beginners ${ }^{49}$ in the study of law. For who would call these jokes from which wrongs result? Such conduct we do not by any means allow and this matter we put under strict regulation for our times and for the future: since our spirits ought to be educated first and then our tongues."

For perhaps three centuries prior to Justinian, neophytes in the law had commenced their student labors with two books of Gaius' Institutes and his four books on wife's property, guardianship, wills and legacies; the second and third years of their course, students took the Praetor's Edict and Ulpian's Commentary thereon followed by the study of eight out of nineteen books of Papinian's Answers; ${ }^{50}$ the fourth-year men read the Answers ${ }^{51}$ of Paulus; and the fifth-year students read the imperial statutes. ${ }^{52}$

But in the year 533 on December 16th, Justinian, who had practically completed his masterly design of codifying Roman law from the dawn of that jurisprudence, then centuries past, laid down ${ }^{53}$ a program of studies modeled according to the arrangement of the titles of the Code already published ${ }^{54}$ and of

44. Papinianistae, because the works of Papinian were studied by them.

45. Const. omnem 5 ; Roby, op. cit., page XXIII.

46. Const. omnem.

47. i. e., Constantinople.

48. i. e., tortious.

49. i. $e$., first-year men, freshmen, were not to be hazed.

50. Const. omnem. Roby, op. cit., page XXVII.

51. Responsa.

52. Constitutiones.

53. Const. omnem; Roby, op. cit., page XXVI-XXVII; Praefatio Institutionum, 5 .

54. First edition, published 529. 
the perpetual edict as compiled by Julian. ${ }^{55}$ Although curing the worst fault of the old program of study-the disregard of the order of the Edict-it was really, aside from the supreme excellence and wider range of the new books to be studied, only the continuation of the purpose and scope of the old plan of study which this decree of Justinian abrogated. For the new books to be studied contained all the old works either in substantia or in modified and renovated form together with the works of very many more of the jurists, some of which were hitherto unknown or not available to lawyers. ${ }^{56}$ Briefly the new program required all students of law to study the entire Corpus Juris (Institutes, Digest and Code), - the whole to take five years' time as formerly. For the first three years, the Institutes and the first five parts of the Digest were to be taken under professional instruction, while the last two years were spent in reading the rest of the Digest and also the Code in private study. ${ }^{57}$

The work of the first year commenced with the reading of Justinian's Institutes in four books, which gave the beginner in the law a rapid survey of the whole field of law, substantive and adjective, civil and criminal. The rest of the year was spent in the study of the first part of the Digest, books 1-4, which comprises introductory and general matters of law. Among the matters treated of in book 1 of the Digest are: fundamental conceptions and definitions of justice and law; origin of law-historical; the kinds and divisions of law with definitions and illustrations; the essentials of the law of persons; adoption and emancipation; what things can be private property; and rights and duties of magistrates and state officials. The student then began the subject of procedure, which he did not finish until the middle of the second year. Digest, book 2, deals with the jurisdiction of courts; sessions of courts, holidays and adjournments; appearance of parties, bills of particulars and the production of documents; cumpromises of doubtful claims and bars to suits. Book 3 treats of motions; infamous persons; actions brought by agents; proceedings in behalf of or against a corporation; actions arising from voluntary agency-negotia gesta; and malicious suits. Book 4, which completed the work of the first year, treats "mainly of the cases, where the ordinary effect of actions and

55. I31 A. D. Eusebius, Chron. (reign of Hadrian)

56. A fairly accurate list preserved in the Florentine MS. contains the names of 38 authors, the titles of 207 treatises and 1,544 volumes or rolls collected in the Digest or Pandects.

57. For details of each of the five years' work, about to be given, see Constitutio omnem, one of the prefatory statutes to the Digest. 
pleas is defeated by annulling the acts on which they rest, in consequence of intimidation, or fraud, or of insufficient age, or other disability of the party attacked." 58 These bars to suits are discussed under restitutio in integrum: alienating the object of the suit; undertakings to act as arbitrator, which title probably attracted the last title of book 4 , - the action against ship-masters and inn-keepers to give up what they have received.

The second year course began with either the second or the third part of the Digest,-books 5-1 I or I2-I9. Ordinarily the third part was reserved for the third year, probably so as to enable the student to finish the subject of procedure continued from the first year. Book 5 at first treats of trials at law, and then begins a detailed study of substantive law, or the subjectmatter of suits, which topic lasted the remainder of the course given under professorial instruction. The "Edictals" began their year's work in the subject-matter of suits by studying book 5 , which treats of real rights or rights in rem; claims to masses of property; of undutiful will, ${ }^{59}$ for the recovery of an inheritance in whole or in part. Book 6 discusses claims to individual things, "it contains the claim to your own property;" ${ }^{60}$ and this was treated . . . first, where the claimant has a good legal title; secondly, where he has an honest title, but requires longer possession to cure defects in the conveyance to him; thirdly, when he has a perpetual lease." ${ }_{1} 1$ Books 7 and 8 treat of personal and real servitudes. ${ }^{6} 2$ Book 9 deals with damage by fault and negligence. ${ }^{63}$ Book ro treats of settling the boundaries of land; ${ }^{64}$ the division of property; ${ }^{65}$ and the production of disputed property before the court or judge. ${ }^{66}$ Then followed book II, of a nature supplementary to these actions in rem and also giving information as to various sundry matters:-interrogatories; consolidation of suits; spoiling or concealing slaves; dice playing; fraudulent surveyors; tombs; funeral expenses; and rights of burial. But in addition to completing the study of suits in rem, the second-year men had to also take the first of the two books on guardianship-Digest, book 26-the first of the two books on

58. Roby, op. cit., page XXXIV.

59. De inofficioso testamento.

6o. Rei vindicatio.

6r. Roby, op. cit., page XXXV.

62. Which correspond respectively in some degree to "estates not of inheritance" and "easements" of the English common law.

63. Lex Aquilia.

64. Actio finium regundorum.

65. Actio familiae erciscundae and actio communi dividundo.

66. Actio ad exhibendum. 
wills-book 28-and the first of the seven books on legaciesbook 30-which furnished the work of the second year.

The third year course of study ordinarily began with the third part of the Digest-books 12-19-or, (if the professors for any reason had required this part to be taken in the second year), with the second part-books 5-1 -already described. The "Papinianists" commenced in this third part the study of obligatory rights, or rights in personam, and took up the subject of contracts and commercial dealings. Books $\mathrm{I}_{2}$ and $\mathrm{I}_{3}$ deal with loans; book 12 treats of loans of money; the recovery of money paid without consideration, or by mistake, or improperly, and summary settlements of such suits on oath tendered. Book 13 deals with the recovery of loans in general $;^{67}$ loans in specie $;^{68}$ and pledge. ${ }^{69}$ Books $14-16$, title $I$, treat of the liabilities of principals on agents' contracts; shipmasters' contracts ; $^{70}$ general average and jettison $;^{71}$ shopkeepers' contracts $;^{72}$ contracts made by slaves and children not emancipated $;^{78}$ and guaranties by women. ${ }^{74}$ The rest of book 16 treats of set-off, ${ }^{75}$ and the contract of deposit. ${ }^{76}$ Books $17-19$ contain the contracts of voluntary agency $;^{77}$ partnership $;^{78}$ purchase and sale $;^{79}$ letting and hiring $;^{80}$ exchange and the like. In addition to the above mentioned books, the third-year students had to take the first half of the fourth part of the Digest, -book 20 on pledge, book 21 on the rescission of purchase and eviction, 81 and book 22 on matters supplementary to the topic of contracts, such as interest, mesne profits, delay, bottomry loans, evidence. ${ }^{82}$ This finished the work for the second year and also the subject of obligatory rights ex contractu.

To the "Lytae," or fourth-year men, were assigned for study

67. Mutuum.

68. Commodatum.

69. Actio pigneraticia.

70. Actio exercitoria.

71. Lex Rhodia.

72. Actio institoria.

73. Senatus consultum Macedonianum.

74. SC. Velleianum.

75. Compensatio.

76. Depositum.

77. Mandatum.

78. Societas.

79. Emptio venditio.

8o. Locatio et conductio.

8r. From the Aediles' Edict.

82. Including proofs and presumptions, witnesses, documentary evidence, the effect of ignorance of law and fact. 
books 23-36 of the Digest, which comprise the latter half of the fourth and all of the fifth parts of the Pandects. The course of study for this year covered the subjects of family law and succession by will. Books 23-25 deal with betrothal; dowry; ${ }^{83}$ gifts between husband and wife; divorce; claims on dissolution of marriage; rights of unborn children; the reciprocal rights of parent and child for support $; 84$ and concubines. Books 26-27 treat of guardian and ward; the appointment and removal of guardians and their responsibility to the ward; the curators of lunatics, spendthrifts, etc. The last topic of the fourth yearsuccessions-was now taken up by the "Lytae." Books 28 and 29 deal with wills and codicils, and books $3^{\circ-36}$, with legacies and trusts. ${ }^{85}$

The fifth and last year of the Justinian program of study was devoted by the "Prolytae" to reading the rest of the Digest, parts six and seven, books $37-50$, and the entire Code. ${ }^{86}$ The subjects dealt with are: succession in spite of and beside a will,books 37 and $3^{8}$, titles $1-5$; intestate succession, ${ }^{87}$-rest of book $3^{8}$; suits between neighbors and gifts inter vivos,-book 39; manumission and claims of freedom,-book 40; acquisition by ownership and possession,-book $4 \mathrm{I}$; judgment and execution,book 42 ; injunctions, ${ }^{88}$ special pleas, bonds, and sureties,books 43-46; crimes and criminal procedure,-books 47-49 to title 13 ; and topics of public law, interpretation of words and expressions, and maxims,-rest of book 49 and book 50 . The remaining work of the year was the study of the twelve books of imperial statutes collected in the Code. The earliest statute in the Code of Justinian is one of the Emperor Hadrian, and only twenty-three are prior to the reign of Severus. The rest are the statutes of subsequent emperors, including Justinian himself. ${ }^{89}$ The subjects of the Code are many and varied, and cover the fields of public law, ecclesiastical law, criminal law,

83. Dos.

84. Alimenta.

85. Fideicommissa.

86. Const. omnem, 5 .

87. In the course of time the students' attention must have been called to two imperial statutes on this subject, promulgated ten and thirteen years respectively after the publication of the Digest,-Novels II 8 and 127 "altering the order of intestate succession to the form of intestate succession to the form which has since prevailed in Europe, and which mainly rules intestate succession to personalty in England (and America) at the present time," Roby, op. cit., page XXXVIII.

88. Interdicta.

89. Prior to the year 534 A.D. 
and civil law. Space will not permit of a lengthy discussion of each book, but the following are some of the important titles: 90 the Catholic faith, churches, bishops, ecclesiastics, heretics, pagans, kinds of law, courts and their jurisdiction, magistrates, and procedure in civil actions,-books $1-2$; actions in rem and real servitudes,-book 3 ; actions in personam and obligations $e x$ contractu,-book 4; family law, marriage and guardianship,book 5 ; wills, codicils, legacies and intestate succession,-book 6 ; prescriptions, attachments, rights of the imperial treasury,book 7 ; injunctions; 91 the paternal power, donations and penalty on celibacy,-book 8 ; crimes and criminal procedure,book 9 ; prerogatives of the imperial treasury (and the State), of unclaimed property, of the kinds of public officers,-book ro; the rights of municipal towns common with the city of Rome, including the rights of bodies corporate,-books II-12. It is quite noticeable that the order of subjects in the Code resembles that of the Digest, - the reason is, because the Digest was modeled partly after the arrangement of subject-matter in the first edition of the Code.

Whether we consider the pre-Justinian or the Justinian programs of study the system of legal education involved was a textbook system. The institutional treatise of Gaius upon which Justinian's Institutes were modeled and from which the latter very frequently excerpted the text bodily, the lucidly exigetical and keenly analytical writings of Papinian, the critical but easily intelligible writings of Ulpian and Paulus, the works of other jurists, nay, even the Digest record the successful development into a scientific form of an enormous mass of cases, rules, decisions and precedents contained in the sources of law.

In the Roman law schools, students spent their first year in getting a bird's-eye view, so to speak, of the entire field of law, -the fundamental conceptions and principles of law being set forth in a logical system and lucid manner intelligible to the novice in jurisprudence. "Who has ever opened the first book of the Institutes of Justinian, or of the Digest without feeling his mind impressed by that stately sequence of definitions and foundation rules." 92 The remaining years of his law course the student devoted to repeatedly going over and reviewing the whole ground covered in the first year, widening and deepening his

9o. For a full list of titles, see Culquhoun, Summary of the Roman Civil Law, 60.

9r. i. e., interdicts.

92. Chief Justice Baldwin, "The Study of Elementary Law," I3 Yale Law Journal, (1903) Ir. 
knowledge of law by a careful, thorough study of the Digest and Code with their detailed expositions and ramifications of juridical doctrines and with illustrations, frequently and of ten copiously introduced in the text, of pertinent cases and recorded decisions. The course of instruction was a "concentric system."93 Mental discipline and the cultivation of habits of clear and accurate thinking were not neglected under this Roman system in legal education. The later years of the student's course could not help to quicken and sharpen the analytical faculty and inductive ability of the student, for some of the illustrative cases of the Digest require close study to be thoroughly appreciated. The student received first a thorough drilling in the elements and principles of the law, which was followed subsequently in the program of studies by the application inductively of what he had previously deductively acquired,-in other words, he learned how to apply legal principles to states of fact.

"The European system of legal education has always been founded on that of the Roman Empire. Roman law was taught as a system of deductive science. The Corpus Juris proceeds from assertions of principles, to their application to various cases. The Institutes are a compendium of elementary law prepared by law school professors ${ }^{94}$ avowedly as a law school textbook. They are followed by the Digest in which the same principles are more fully stated and illustrated. Then follows the statute law of recent times. Can indeed, in the nature of things, a science like law be intelligently taken up by anyone who has never been introduced to an acquaintance with its fundamental terms and conceptions?" 95

The Roman law is "the most celebrated jurisprudence known to the world;" that it still lives to-day clothed, not in a sixth, but a twentieth century dress, is due in no small measure to its splendid program of legal education which so successfully trained jurists perhaps unsurpassed in creative ability by any body of lawyers in the world's history. Roman legal education, if judged by the educational criteria of thoroughness, completeness, mental discipline, and the cultivation of the power of thought,-in other words, by what it did for those whom it educated-is worthy to be ranked with the best modern legal instruction.

Charles P. Sherman.

93. See Wurts, "Systems in Legal Education." I Y Yale Law Journal, p. 95.

94. Theophilus and Dorotheus. The celebrated Tribonian was the president of Justinian's codification commission.

95. Ch. J. Baldwin, Id. page 12. 